\title{
Vulnerability of specialty crops to short-term climatic variability and adaptation strategies in the Midwestern USA
}

\author{
Erica Kistner $^{1}$ • Olivia Kellner ${ }^{2}$ - Jeffrey Andresen ${ }^{3}$. \\ Dennis Todey ${ }^{1} \cdot$ Lois Wright Morton ${ }^{4}$
}

Received: 24 January 2017 / Accepted: 21 August 2017 /Published online: 22 September 2017

(C) The Author(s) 2017. This article is an open access publication

\begin{abstract}
While the Midwestern USA ranks among the world's most important corn-soybean production regions, the area also produces a variety of high-value specialty crops. These crops are an important component of the region's rural economy with an estimated value of $\$ 1.8$ billion in 2012. More profitable per-acre than many row crops, specialty crops also have higher production-related risks. They are generally more sensitive to climatic stressors and require more comprehensive management compared to traditional row crops. Temperature and precipitation fluctuations across the Midwest directly impact specialty crop production quantity and quality and indirectly influence the timing of crucial farm operations and the economic impacts of pests, weeds, and diseases. Increasingly variable weather and climate change pose a serious threat to specialty crop production in the Midwest. In this article, we assess how climate variability and observed climatic trends are impacting Midwestern specialty crop production using USDA Risk Management Agency data. In addition, we review current trends in grower perceptions of risks associated with a changing climate and assess sustainable adaptation strategies. Our results indicate that weather-induced losses vary by state with excessive moisture resulting in the highest total number of claims across all Midwestern states followed by freeze and drought events. Overall, specialty crop growers are aware of the
\end{abstract}

This article is part of a Special Issue on 'Vulnerability Assessment of US Agriculture and Forests developed by the USDA Climate Hubs' edited by Jerry L. Hatfield, Rachel Steele, Beatrice van Horne, and William Gould.

Electronic supplementary material The online version of this article (https://doi.org/10.1007/s10584-0172066-1) contains supplementary material, which is available to authorized users.

Erica Kistner

erica.kistner@ars.usda.gov

1 USDA Midwest Climate Hub, Ames, IA 50011, USA

2 Illinois State Water Survey, Champaign, IL 61820, USA

3 Michigan State University, East Lansing, MI 48824, USA

4 Iowa State University, Ames, IA 50011, USA 
increased production risk under a changing climate and have identified the need for cropspecific weather, production, and financial risk management tools and increased crop insurance coverage.

\section{Introduction}

Commonly known for its role as a primary producer of grains and oilseed crops, the Midwestern USA (defined as Illinois, Indiana, Iowa, Michigan, Minnesota, Missouri, Ohio, and Wisconsin) is also home to a wide variety of specialty crops that accounted for just under $\$ 2$ billion of total farm gate value in 2012 (USDA-NASS 2015). Major crops produced in the region include both long-lived perennial species such as tree fruit and nuts as well as a wide variety of spring-planted annuals. While these crops are grown on only $0.6 \%$ of the region's cropland, they account for $2.7 \%$ of its crop-related market value (USDA-NASS 2015). However, these high-value crops require more stringent management than traditional row crops and are more sensitive to climatic stressors (Walthall et al. 2012). Regional changes in temperature and precipitation are already directly impacting specialty crop production via crop quantity and quality, as well as indirectly influencing the timing of crucial farm operations. In addition, projected climatic changes in this region are expected to further impact management decisions and productivity of a wide range of specialty crops grown in the Midwest. This paper focuses on our current understanding of the vulnerabilities in Midwestern specialty crop production under a changing climate, an analysis of USDA Risk Management Agency Cause of Loss Data for specialty crops in this region, and potential adaptation strategies. Additionally, we review grower perceptions of production risks associated with an increasingly variable climate and assess their adaptive capacity under future climate projections.

More than 30 primary specialty crops produced in the region are operationally monitored by the National Agricultural Statistics Service (Fig. 1). In contrast to the region's corn and soybean production, which tend to be associated with deep soils with relatively high organic matter content and water-holding capacities, most specialty crop production tends to be concentrated in areas with relatively lighter, coarse-textured soils such as the central sands area of central Wisconsin, the Illinois River Valley in central Illinois, and the fruit-belt region of western Lower Michigan (Supplemental Fig. S.1). Soils with greater hydraulic conductivity are preferable for specialty crop production due to relatively rapid drainage rates and high trafficability characteristics (USDA-NRCS 2006). Consequently, most of the specialty crops are irrigated, with just under 1.1 million irrigated acres on farms with specialty crops in 2012 (USDA-NASS 2015). Many of the crops are grown in proximity to the Great Lakes which modify regional climate by reducing temperature extremes, delaying bloom in the spring and reducing risk of freeze damage (Andresen and Winkler 2009).

By acreage, the five most widely grown specialty crops (in descending order) are sweet corn, green peas, potatoes, snap beans, and popcorn. By market value, the five largest are apples, potatoes, sweet corn, cranberries, and blueberries (USDA-NASS 2015). The area involved in the production of specialty crops increased slightly from 646,841 acres in 2009 to 747,480 acres in 2014 , which is similar to overall percentage changes in cropland in the region. At the same time, the cash market value increased from $\$ 1.62$ billion to $\$ 1.78$ billion (USDA-NASS 2015). Factors associated with these changes include increases in agro-tourism, the farm-to-table movement for non-genetically modified produce, and the introduction of 


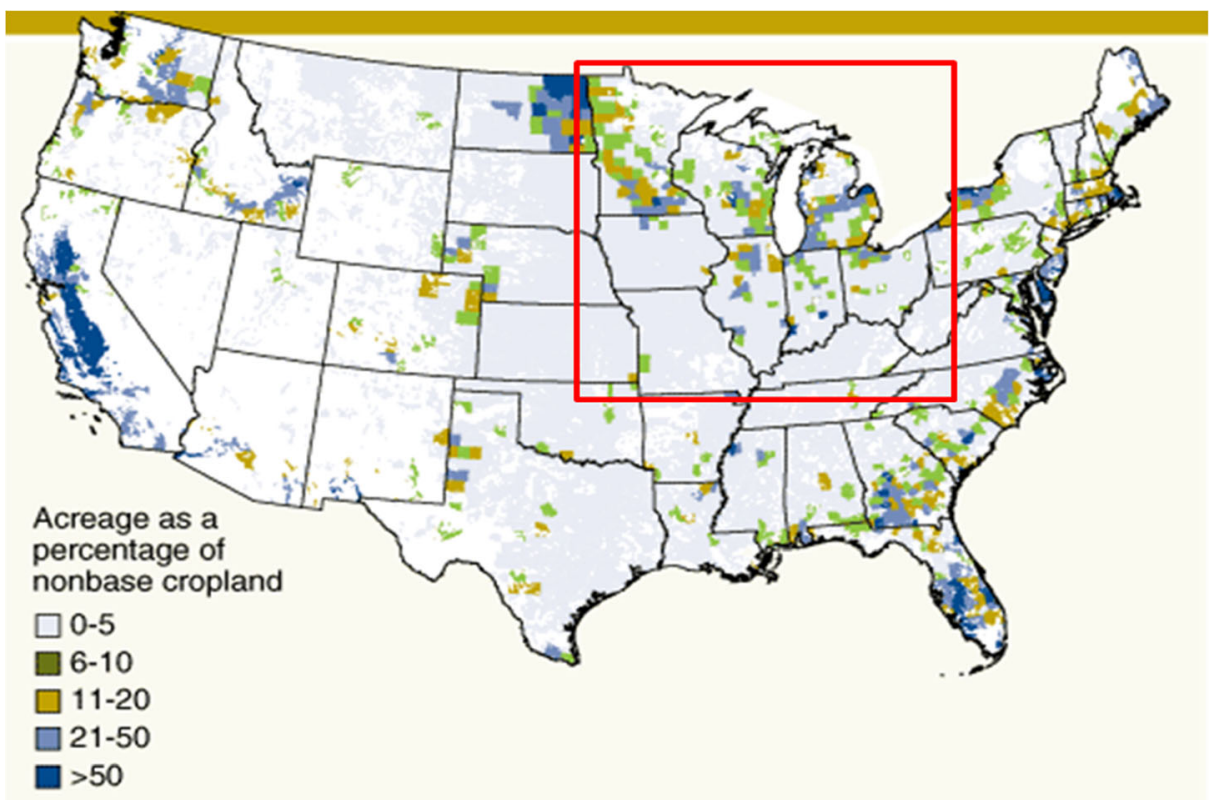

Source: Compiled by USDA, Economic Research Service from USDA, Farm Service Agency data.

Fig. 12003 map of continental USA showing percent of cropland acreage dedicated to fruit and vegetable production out of the total cropland acreage in use. From Young et al. 2007

international competitors driven by the 1994 WTO agreements and growing concern of genetically modified (GM) crops (Veeck et al. 2006).

Specialty crops typically require more intensive management than row crops. Product quality, as well as quantity, is a critical factor. However, they are potentially more profitable for farmers. Unfortunately, specialty crops are also more sensitive to temperature and precipitation amounts and frequency (i.e., climatic stressors) than row crops (Walthall et al. 2012). Because they require more agronomic care and are often grown on limited acreage, these high values crops are more difficult to insure with crop insurance (Crane et al. 2010). Reduced specialty crop yields have been a primary concern in assessing climate variability impacts. However, specialty crops also experience changes in nutrients and properties such as color, visual appeal, aroma, taste, and texture during stressful climatic conditions (Ahmed and Stepp 2016). It is these product quality characteristics that influence consumer purchasing decisions and willingness to pay premium prices. Thus, the climatic sensitivity of specialty crops poses production and economic risks to producers under projected increasing weather variability and shifts in climate.

The 3rd US National Climate Assessment reports that the Midwest observed more than a $0.8{ }^{\circ} \mathrm{C}$ increase in average temperature from 1900 to 2010 with relatively more rapid warming beginning in the latter half of the twentieth century. From 1950 to 2010, the average temperature increased at twice the rate compared to the previous five decades, and from 1980 to 2010 , the average temperature increased three times as quickly compared to the previous eight decades (Pryor et al. 2014). Much of the warming has been observed in warmer overnight low temperatures, with overall warming most prevalent during the winter season compared to spring, summer, and fall (Pryor et al. 2014). These warming trends have led to a 
longer growing season (i.e., increased frost-free period). However, the warmer winters promote plant development before the last spring freeze, resulting in earlier dormancy breaks and putting many fruit and vegetable crops at risk for spring freeze. Annual precipitation and the frequency of heavy precipitation events have also increased over the last century, with more precipitation observed in the spring, which disrupts planting and crop establishment (Kunkel et al. 2012; Pryor et al. 2014). These observed changes, alongside projected changes in the Midwest climate, have placed specialty crop production at high risk for loss.

Although average temperatures in the Midwest have increased, the warming trend has not been uniform across the region. Consequently, specialty crop impacts associated with drought and extreme heat events vary greatly by location, which complicates production management strategies. Research on West Coast growers experiencing excess heat and drought have found that perceived changes in past water availability and increased summer temperature are influencing concern about adaptive management to climate change (Olen et al. 2015). In an increasingly wet climate like the upper Midwest, grower concerns are more focused on managing excess water and seasonal rather than long-term drought. In addition, the timing of precipitation strongly influences management decisions such as days available for field work (e.g., soil prep, planting, harvest), weed and pest management, and spray regimes.

In the upper Midwest, a 2012 random sample survey of almost 5000 corn-soy growers revealed that farmers have heterogeneous experiences with flooding, saturated soils, and drought that are locale specific; and these experiences affect perceptions of risk and adaptive management practices (Morton et al. 2015). Many farmers are confident they will be able to deal with increases in weather variability, and they support public and private efforts to help farmers adapt to increased variability (Arbuckle et al. 2014; Morton et al. 2015). However, very little is known about upper Midwest specialty crop growers' perceptions of increasingly variable weather and the risks associated with changing climatic conditions.

To address this shortcoming, we examined vulnerabilities of Midwestern specialty crop production to weather and climate variability. The objectives of this assessment are to (1) determine recent trends in Midwestern specialty crop losses due to weather hazards using USDA Risk Management Agency data; (2) review literature on current and predicted future climate-/weather-related vulnerabilities in this region; (3) summarize grower perceptions of these issues; and (4) discuss possible adaptation strategies that reduce production risks in light of a changing climate. Our assessment is limited to fruit, vegetable, and tree nut crops given that most floricultural crops in the region are produced in partially or completely climate-controlled structures with glass or plastic covers.

\section{Assessment of recent weather-related crop disaster data}

To investigate trends in Midwest specialty crop losses due to weather hazards over time, the USDA Risk Management Agency (RMA)'s regional data from 1989 to 2015 (USDA-RMA 2015) were assessed with a focus on climate-driven impacts. RMA collects and archives "Cause of Loss" data for all insured crops produced in the USA. Figure 2 presents the total annual indemnity claimed by specialty crop producers in the Midwest for the years 1989-2015. Weather and climate-driven cause of loss from specialty crop claims include cold wet weather, cold winter, 


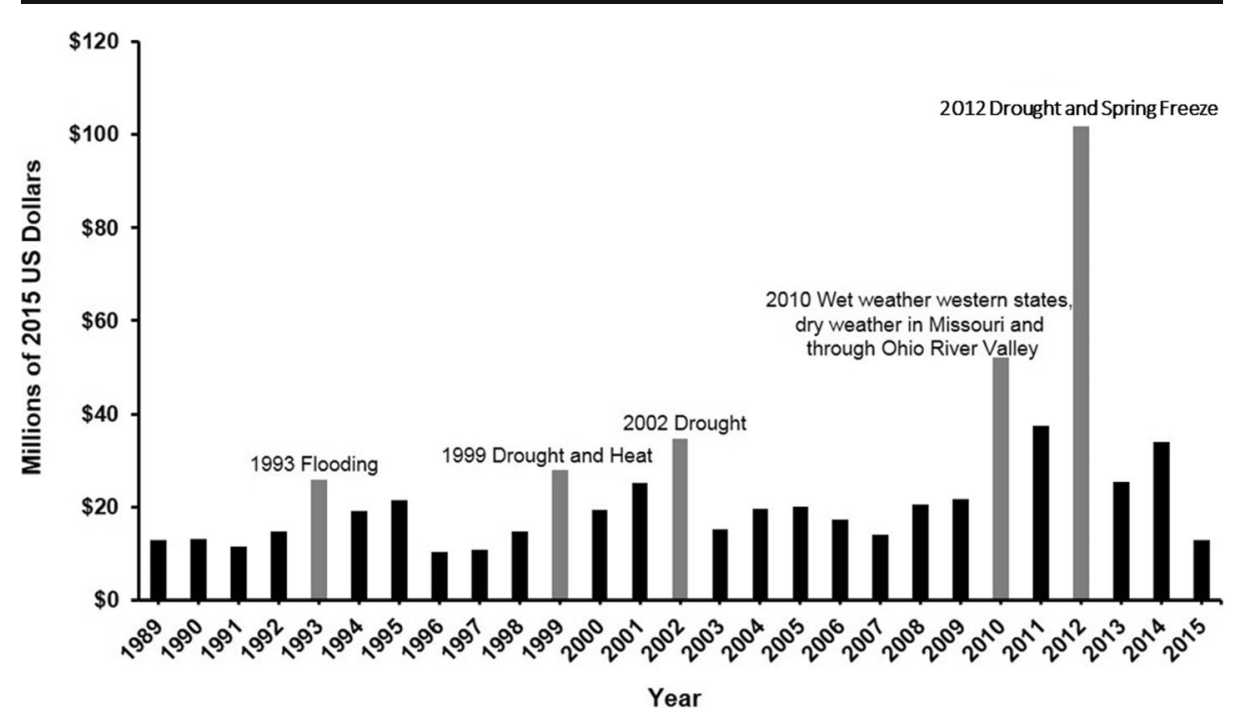

Fig. 2 Midwestern USA annual indemnity costs for specialty crop losses due to weather and climatic events from 1989 to 2015. Gray bars highlight years with major weather and climatic events. Annual indemnity costs were summed across Illinois, Indiana, Iowa, Michigan, Minnesota, Missouri, Ohio, and Wisconsin on a per year basis

drought, excess moisture/precipitation/rain, flood, freeze, frost, hail, heat, hot wind, wind/excess wind, hurricane, and other events (e.g., snow, lightning) as well as indirect impacts that influence losses from insects and diseases. An important caveat of this dataset is that the cause of loss associated with each claim was self-reported by individual producers. Area-wide differences in most frequently reported weather hazards and ensuing crop loss claims are summarized in Table 1.

Crop insurance availability for specialty crops has increased over the last decade as a result of the increased government assistance provided to producers in the wake of weather disasters such as Hurricanes Katrina and Sandy, the 2012 drought, and the growth of production in hazard-prone areas (GAO 2014). From 2000 to 2010, the value of specialty crops (fruits, nuts, vegetables, melons, greenhouse, and nursery) increased from $\$ 41.8$ billion of US farm cash receipts to $\$ 57$ billion of US farm cash receipts (Collins 2012). Subsequently, a surge in specialty crop insurance has occurred from approximately $\$ 7.5$ billion in 2000 to $\$ 15.5$ billion in 2015 with the largest increases in insurance covering fruits, nuts, and trees (USDA-RMA 2015). However, there are still many widely produced specialty crops that are not insured. Thus, the data in Fig. 2 should not be viewed as a comprehensive summary of annual loss due to weather hazards. Nevertheless, it is the primary data currently used to assess climatic impacts such as drought, excess moisture, freeze events, and frost events on specialty crops.

\section{Review of climate-/weather-related vulnerabilities}

\subsection{Drought impacts to specialty crops}

Despite increased annual precipitation, several major droughts have impacted the Midwest in recent decades (1983, 1988, 2002, and 2012). Furthermore, climate projections indicate that longer dry periods will occur between precipitation events across the Midwest in the future 
Table 1 Summary of Risk Management Agency (RMA) crop loss data by state due to weather-related hazards from 1989 to 2015

\begin{tabular}{llll}
\hline State & Top 3 claimed weather hazards & Top 3 claimed specialty crops & $\begin{array}{l}\text { Cumulative indemnity cost } \\
\text { (2015 US dollars) }\end{array}$ \\
\hline Iowa & Excess moisture, drought, heat & Popcorn, sweet corn, potatoes & $\$ 8,160,600$ \\
Illinois & Excess moisture, drought, heat & Popcorn, green peas, sweet corn & $\$ 19,268,406$ \\
Indiana & Excess moisture, drought, heat & Popcorn, mint, tomatoes & $\$ 35,125,464$ \\
Michigan & Freeze, frost, excess moisture & Apples, grapes, peaches & $\$ 160,264,695$ \\
Minnesota & Excess moisture, heat, drought & Green peas, sweet corn, potatoes & $\$ 173,367,509$ \\
Missouri & Excess moisture, drought, hail & Popcorn, apples, potatoes & $\$ 16,462,863$ \\
Ohio & Excess moisture, drought, freeze & Popcorn, tomatoes, apples & $\$ 18,286,110$ \\
Wisconsin & Excess moisture, drought, heat & Green peas, sweet corn, cranberries & $\$ 62,920,725$ \\
\hline
\end{tabular}

${ }^{\text {a }}$ Cumulative indemnity costs are summed across all claimed specialty crops and weather-related hazards from 1989 to 2015 on a per state basis

(Hatfield et al. 2014; Mir et al. 2012; Pryor et al. 2014). Specialty crops grown across the Midwest whose quality is directly impacted by rainfall (or lack thereof) include cherries (Sekle 1995), apples (Vallat et al. 2005), and grapes (Xu et al. 2011). However, drought (and commonly concurrent warmer temperatures) (Koster et al. 2009) impacts the quality of a vast variety of fruit and vegetable crops (Moretti et al. 2009). Unlike corn and soybean, a majority of specialty crops are less affected by drought conditions because they are irrigated (Hogan 2013). The 2012 Census of Agriculture reports that approximately $62.5 \%$ of specialty crop acres are irrigated, with approximately $48.6 \%$ of irrigated acres being orchards, followed by $34.2 \%$ in vegetables (Vilsack and Reilly 2015). However, if crop water demand exceeds the available water supply, crop damage can result. This is most important during pollination and fruit-set time for most vegetable crops (Chatterjee and Solankey 2015). Sweet corn, an abundant specialty crop grown in the Midwest, flowers only once. If the crop is waterlimited during ear filling, it will produce poor ear fill (Rubatzky and Yamaguchi 2012). Grapes are more likely to be impacted by prolonged drought because they have deeper root systems. With prolonged drought, fruit on the vines may not ripen (Maurer 2012).

\subsection{Frost and freeze impacts to specialty crops}

Extreme temperature fluctuations during the spring can have enormous impacts on specialty crops. Cold temperatures infiltrated the Midwest specialty crop growing region during the springs of 2007 and 2012, severely damaging crops each year. Each event was preceded by an extended period of warmer than normal temperatures that caused perennial crops to break dormancy and begin growing earlier than normal. Identified as a "false spring" (Marino et al. 2011), the week prior to April 5-7, 2007, saw daily minimum temperatures in excess of $15{ }^{\circ} \mathrm{C}$ in central Missouri. This was followed by a shift in the jet stream that moved arctic air into the Central and Eastern USA for about a week. During the event, temperatures plummeted to as cold as $-7{ }^{\circ} \mathrm{C}$ resulting in agricultural losses of about $\$ 2$ billion (Marino et al. 2011). Crop damage was substantial but limited to northern Missouri and southwest Iowa where warmer temperatures the prior week resulted in loss of dormancy and vegetative growth.

During March, 2012, a persistent upper air ridging feature set up across much of eastern two thirds of North America and led to a 3 week period of abnormally warm 
temperatures resulting in the warmest March on record (1895-2015 period of record) at many locations across the Midwest (Labe et al. 2016). Overwintering vegetation across the Great Lakes region broke dormancy weeks before normal, leaving it highly susceptible to frost or freeze damage. Near the end of March and throughout April 2012, normal temperatures returned to the region, including a series of frost and freeze events (climatological normal last freezing temperatures in the region tend to occur in late April or early May). Blooms and early developing fruits were severely damaged or lost due to the freezing temperatures. Michigan alone lost approximately $85 \%$ of their apple crop and $90 \%$ of their tart cherry crop for the year, likely the worst single weather-related loss in the 150 years tree fruit has been grown commercially in the region. The total loss inclusive of blueberries, grapes, peaches, sweet cherries, and asparagus was estimated at \$209.8 million (Knudson 2012). Wisconsin also lost much of its cherry and apple crops, and Illinois experienced extensive freeze damage to its apple crop in central and northern counties (Sigler 2012).

\subsection{Excessive moisture and precipitation}

Excess moisture was the costliest to specialty crops in the Midwest states of Minnesota, Wisconsin, Illinois, and Missouri from 1989 to 2015, according to USDA-RMA. It ranks second most costly in the states of Iowa, Indiana, and Ohio. It is Minnesota's most commonly claimed specialty crop hazard. Overall, Midwestern producers have claimed over $\$ 130$ million in losses due to excess moisture, precipitation, or rain alone. The three worst years were 1999, 1993, and 2001, respectively (adjusted to 2015 dollars). Two federal disaster declarations were made that year for Minnesota due to severe ice storms, flooding, and heavy rain (FEMA 2016). During the 9 years prior to 2013, southern Minnesota experienced three 1000-year flood events (Durgan 2013). In 2015, central Illinois (which produces $90 \%$ of the country's canned pumpkin) received $58.9 \mathrm{~cm}$ of rain from May to July (nearly double the average). The excess moisture greatly reduced the pumpkin harvest, leading to a shortage of canned pumpkins in 2015 (Angel 2015).

\subsection{Dynamic weeds, insects, and disease pressures}

As temperatures and the frequency of extreme weather events continue to increase, pest outbreaks (weeds, diseases, and insects) and subsequent economic damage to Midwestern cropping systems are expected to become more frequent and severe (Hatfield et al. 2014; Pryor et al. 2014). Over the last 50 years, warming temperatures have enabled numerous crop pests and pathogens to expand their ranges northward thereby challenging Midwestern growers to monitor and manage them (Bebber et al. 2013). Warming minimum winter temperatures in the Midwest benefit many insect pests by decreasing rates of overwintering mortality. In addition, rising annual temperatures may also increase the number of generations in multivoltine insects which in turn can greatly exacerbate the potential economic damage caused by these pests (Tobin et al. 2008). Increased spring precipitation and higher temperatures across the Midwest may be enhancing fungal and bacterial plant pathogens (Anderson et al. 2004). For instance, outbreaks of bacterial spot, a severe bacterial pathogen of cucurbit crops linked to precipitation, have drastically increased across pumpkin fields in Illinois over the past decade (Ravanlou and Babadoost 2015). There is a general consensus that the impact of weeds should increase under future climatic projections especially in terms of species distributions (Dukes 
and Mooney 1999). Furthermore, invasive weeds may be able to adapt more quickly to changing climatic conditions within agroecosystems giving them the competitive edge over crops in obtaining limiting resources like water, nitrogen, and light (Clements and Ditommaso 2011).

\subsection{Threats to pollination services}

Insect pollination services are a crucial component of the US agricultural industry and are currently valued at $\sim \$ 15$ billion per year (Calderone 2012). Many high economic value specialty crops grown in the Midwest (e.g., apples, blueberries, pumpkins) are dependent on bee pollination services. Alarmingly, North American bee populations (both domestic and wild) have declined over the past two decades with rising temperatures emerging as key factor in declining bumble bee populations (Kerr et al. 2015; Potts et al. 2010). To further complicate matters, pollinators are vulnerable to a wide range of pesticides whose utilization in the Midwest may rise given that crop pest impacts are expected to increase under future climatic projections and the efficacy of pesticides decreases under extreme rainfall events (Hatfield et al. 2014).

\section{Future projections}

In the near term (and within the strategic decision time-span of many crops), similar trends and variabilities in weather and climate are likely to continue. Longer-term projections are more variable based on potential greenhouse gas emissions and management efforts. Overall annual average temperatures are expected to increase $1.9-2.8^{\circ} \mathrm{C}$ by $2041-2070$ relative to $1971-2000$ averages which suggests continued pressure on specialty crop production (Hatfield et al. 2014). Projected increases in the number of days above $35^{\circ} \mathrm{C}$ and warm nights will increase the growing season length, but also introduce potentially more stressful days, particularly in the southern part of the Midwest. Additionally, warmer nights will increase plant respiration rates and consume fixed carbon, potentially reducing yields. Warmer winters will enhance survival of overwintering of insects which in turn may lead to increased pest pressures (Tobin et al. 2008).

Under future climate change projection scenarios, rainfall patterns are expected to shift and become more erratic: average precipitation is expected to increase $4.1-10.2 \mathrm{~cm}$ by 2041-2070 relative to the 1971-2000 average precipitation. Overall, the number of days with heavy precipitation during this future time frame is also expected to increase, coupled with an increased number of dry days between rainfall events (Pryor et al. 2014). Precipitation projections also suggest increased winter and spring seasonal totals with reduced summer totals. This creates a double stress on specialty crop producers and their crops with increased spring wetness and management issues followed by drier summers. Potential summer moisture deficits could be exacerbated by increased temperatures and longer growing seasons which increase the overall crop water use. Climatic variability is expected to increase as well (Melillo et al. 2014). Projected climatic shifts are also expected to lead to increased weed, disease, and insect pest pressures which, when coupled with increasing frequencies of extreme weather events, would impact management decisions and productivity of a wide range of specialty crops grown in the Midwest (Hatfield et al. 2014). Thus, future climate regimes may exacerbate 
management challenges more so than already witnessed in recent decades unless adaptation and mitigation to climate variability and change is undertaken by producers.

\section{Adaptation to a changing climate}

\subsection{Growers perceptions of threats}

To assess specialty crop vulnerability and develop effective adaptation strategies, it is useful to understand the direct and indirect impacts of weather and climate on Midwestern specialty crop production as experienced by growers. Johnson and Morton's (2015) study of 129 Michigan and Ohio specialty crop grower leaders identified and ranked production issues associated with a changing climate and extreme weather events. Among the nine major production impacts identified by growers in this region, pests and disease (new invasive species), marketing and risk (increased need for financial risk management tools), and water (increased demand for water) related issues were ranked as their top three greatest concerns (Fig. 3). Growers also ranked the following weather/climate issues as highly important: fluctuations in spring temperature and fruit bud break; early spring warming and late frost (affects tree fruit), and excessive rainfall in spring (affects planting dates). In addition to weather/climate direct impacts on their production systems, a number of indirect effects were identified and highly rated: increased variability in crop quality and quantity; increased workforce instability; and reduction in farm profitability. Overall, growers expressed a heightened sense of increased crop risk under changing climate and extreme weather events, but

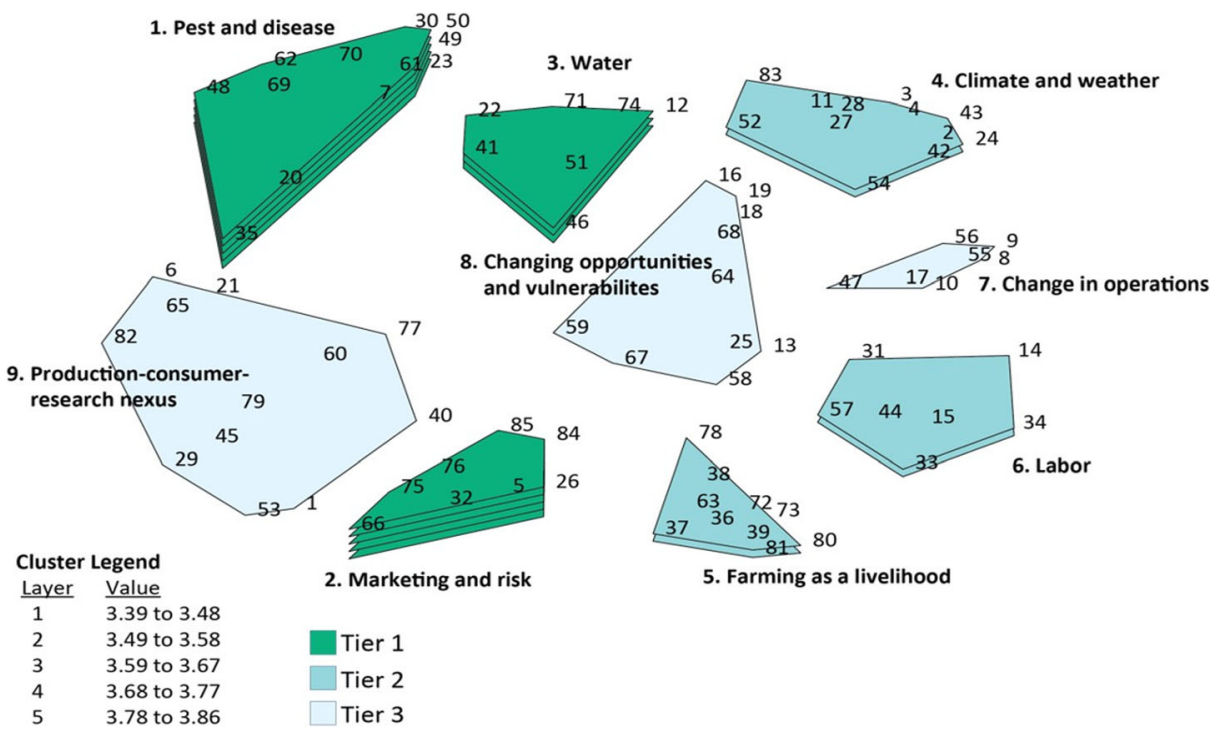

Fig. 3 Nine cluster rating map generated from Midwest specialty crop leaders' brainstorm, rating, and sorting process in 2014. Growers identified 85 key climate-/weather-related issues impacting their production systems. These statements were then rated $(1=$ not at all important to $5=$ extremely important $)$ and mapped into nine clusters representing production issues of highest concern. Clusters with more stacked levels indicate higher rating grand means. From Johnson and Morton 2015 
believed there were opportunities for new approaches to plant varieties and new types of crops as well as the potential to expand production in the Midwest due to decreased production elsewhere.

\subsection{Adaptation strategies}

Midwestern specialty crop growers are likely to continue to experience severe crop losses due to increasingly variable and extreme weather events. A few major impacts have been discussed here. Given the limited crop insurance coverage available to many specialty crop growers, developing appropriate adaptation and management strategies is crucial. To date, the impact of early spring freezes on perennial specialty crops have attracted the most attention (Marino et al. 2011). Irrigation sprinklers, heaters, and more recently frost fans are currently being used by Midwestern fruit growers to mitigate frost damage. Unfortunately, no one method is completely effective and a combination of methods is often warranted (Sigler 2013). High tunnel covers may also be a good option for growers in Michigan and Ohio where fruit and vegetable crop losses due to extreme temperature events are common (Carey et al. 2009). One promising new indirect strategy is the application of sprayed water mist early in the growing season to cool plant tissue and delay phenological development, leaving the crop less susceptible to any freezing temperatures (Rijal 2017). For annual specialty crops (especially green peas and sweetcorn), losses due to excessive moisture account for the majority of reported losses in Midwestern states with the exception of Michigan (USDA-RMA 2015). Tile drainage is becoming a much more common practice for removing excess water in Midwestern row crop agriculture, but it is not currently widely used in specialty crop systems. Cover crops can help maintain soil integrity in the face of heavy rains while simultaneously suppressing weed establishment in vegetable cropping systems (Nair et al. 2015).

Drought and high temperatures are also major causes of reported specialty crop losses with cole crops being particularly vulnerable. Improved water management, new heat tolerant varieties, or switching to alternative crops may be viable strategies as extreme heat events become more frequent and severe (Hatfield et al. 2014, Mir et al. 2012). While irrigation decision-making tools are currently being developed for specialty crop systems in California (Johnson et al. 2013), such tools are more limited for Midwestern producers despite grower concerns over water availability (Johnson and Morton 2015).

All specialty crop producers would benefit from more accurate long-term climate and short-term weather forecasts at higher spatial resolutions. Given uncertainties regarding seasonal weather patterns and climate change projections at fine spatial scales, a more diversified farm may be buffered from weather-related crop losses due to pests, diseases, and weeds (Walthall et al. 2012). For instance, a grower that plants sweet corn can more easily overcome yield losses from an unexpected outbreak of corn earworm if pumpkins are also grown. Further research is greatly needed to develop a robust toolkit of adaptation measures to meet the diverse needs of Midwestern specialty crop farmers. Unlike traditional row crops, there is often little to no tolerance for weather-induced reductions in commodity quality which makes effective climate resilient practices all the more critical for sustaining Midwestern specialty crop production under an increasingly variable climate.

\subsection{Grower capacity for adaptation}

Adaptation is the collective set of short- and longer-term grower adjustments made in response to perceived or actual conditions that they consider will affect their crops. These adjustments may be made to avoid threats to their production system or to take advantage of new opportunities as the 
situation and/or resources change. Survey results from US farmers reveal that intentions to adapt to climate change are influenced by previous climate experiences and concerns about local impacts (Haden et al. 2012; Morton et al. 2015). Further, there is evidence that the high uncertainties in long-term projections of climate at finer spatial and temporal scales can limit grower adaptive management decisions (Howden et al. 2007). Changes in the timing of labor needs, which influence scheduling, harvesting and processing, were concerns in the MichiganOhio research (Johnson and Morton 2015). Poor crop quality and quantity especially impact migrant labor earning capacity, and crop loss from freezes and other weather events change the timing, or in some instances, destroy the crop and eliminate the need for labor (Johnson and Morton 2015). In addition, one year's crop loss can disrupt future availability of labor. Local experience and context seem to be variables driving adaptive management (Haden et al. 2012). Michigan and Ohio growers identified a need for more financial and other types of flexible risk management tools to help them better respond to changing weather and climate (Johnson and Morton 2015). There is a need for crop-specific research on the interaction between weather variability and growers' management decisions associated with those systems of production.

\subsection{Knowledge gaps}

Our assessment provides a snapshot of challenges facing Midwestern specialty crop production in a changing climate and grower perceptions of risks and opportunities. The RMA crop loss data was somewhat limited for specialty crops grown in the Midwest. High-value crops not included in this study include horseradish, asparagus, and watermelons. The survey conducted by Johnson and Morton (2015) was comprised mainly of major specialty crop producers in the region. A stratified random sample survey of Midwest specialty crop growers is greatly needed to better assess the current beliefs, concerns, and practices associated with a variable climate as well the resources needed to ensure specialty crop production remains viable under increasingly stressful climatic conditions. Improved short- and long-term weather forecasting as well as economic decision-making tools is warranted to help producers maintain sustainable crop systems under projected increased abiotic and biotic stressors.

Acknowledgements The authors would like to thank Dr. Jerry Hatfield and Dr. Beth Hall for their initial work on specialty needs. They would like to recognize Anna Johnson for her efforts on gathering specialty crop producer attitudes and the producers themselves for their willingness to share information about their production issues. They thank Charlene Felkley for helpful feedback and comments. Any opinions, findings, and conclusions or recommendations expressed in this publication are those of the author(s) and do not necessarily reflect the views of the Illinois State Water Survey.

Open Access This article is distributed under the terms of the Creative Commons Attribution 4.0 International License (http:/creativecommons.org/licenses/by/4.0/), which permits unrestricted use, distribution, and reproduction in any medium, provided you give appropriate credit to the original author(s) and the source, provide a link to the Creative Commons license, and indicate if changes were made.

\section{References}

Ahmed S, Stepp JR (2016) Beyond yields: climate change effects on specialty crop quality and agroecological management. Elem Sci Anth 4:000092. https://doi.org/10.12952/journal.elementa.000092

Anderson PK, Cunningham AA, Patel NG, Morales FJ, Epstein PR, Daszak P (2004) Emerging infectious diseases of plants: pathogen pollution, climate change and agrotechnology drivers. Trends Ecol Evol 19: 535-544. https://doi.org/10.1016/j.tree.2004.07.021 
Andresen JA, Winkler JA (2009) Weather and climate. In: Schaetzl RJ, Brandt D, Darden JT (eds) Michigan geography and geology. Pearson Custom Publishing, Boston, MA, pp 288-314

Angel J (2015) The Great Pumpkin Shortage of 2015. Illinois State Climatologist: October 2015. Illinois State Water Survey, Champaign, IL. https:/climateillinois.wordpress.com/2015/10/07/the-great-pumpkinshortage-of-2015-in-illinois/. Accessed 9 Jan 2017

Arbuckle JG, Hobbs J, Loy A, Morton LW, Prokopy LS, Tyndall J (2014) Understanding corn belt farmer perspectives on climate change to inform engagement strategies for adaptation and mitigation. J Soil Water Conserv 69:505-516. https://doi.org/10.2489/jswc.69.6.505

Bebber DP, Ramotowski MA, Gurr SJ (2013) Crop pests and pathogens move polewards in a warming world. Nat Clim Chang 3:985-988. https://doi.org/10.1038/nclimate1990

Calderone NW (2012) Insect pollinated crops, insect pollinators and US agriculture: trend analysis of aggregate data for the period 1992-2009. PLoS One 7:e37235. https://doi.org/10.1371/journal.pone.0037235

Carey EE, Jett L, Lamont WJ, Nennich TT, Orzolek MD, Williams KA (2009) Horticultural crop production in high tunnels in the United States: a snapshot. HortTechnology 9:37-43

Chatterjee A, Solankey SS (2015) Functional physiology in drought tolerance of vegetable crops: an approach to mitigate climate change impact. In: Choudhary ML, Patel VB, Siddiqui MA, Sharaz MS (eds) Climate dynamics in horticultural science, Principles and applications, vol 1. CRC Press, Boca Raton, pp 149-171

Clements DR, Ditommaso A (2011) Climate change and weed adaptation: can evolution of invasive plants lead to greater range expansion than forecasted? Weed Res 51:227-240. https://doi.org/10.1111/j.13653180.2011.00850.x

Collins K (2012) Crop insurance and specialty crops. Today Magazine. http://www.cropinsuranceinamerica. org/wp-content/uploads/Specialty-Crops-FINAL.pdf. Accessed 19 Oct 2016

Crane TA, Roncoli C, Paz J, Breuer N, Broad K, Hoogenboom G (2010) Forecast skill and farmers' skills: seasonal climate forecasts and agricultural risk management in the southeastern United States. Wea Climate Soc 2:44-59. https://doi.org/10.1175/2009WCAS1006.1

Dukes JS, Mooney HA (1999) Does global change increase the success of biological invaders? Trends Ecol Evol 14:135-139. https://doi.org/10.1016/S0169-5347(98)01554-7

Durgan B (2013) Seeking patterns. Mark Seeley charts Minnesota's changing climate. University of Minnesota Extension. Magazine of Extension research and education. Fall 2013. http://www.extension.umn. edu/source/fall-2013/docs/source-fall-2013.pdf. Accessed 1 Dec 2016

Federal Emergency Management Agency (FEMA) (2016) Disaster declarations for Minnesota. DR -1283 and DR-1288. https:/www.fema.gov/hi/disasters/grid/state-tribal-government/57. Accessed 1 Dec 2016

Government Accountability Office (2014) Climate change: better management of exposure to potential future losses is needed for federal flood and crop insurance. GAO-15-28. United States Government Accountability Office, Washington DC, p 48

Haden VR, Niles MT, Lubell M, Perlman J, Jackson LE (2012) Global and local concerns: what attitudes and beliefs motivate farmers to mitigate and adapt to climate change. PLoS One 7:e52882. https://doi. org/10.1371/journal.pone.0052882

Hatfield J, Takle G, Grotjahn R, Holden P, Izaurralde RC, Mader T, Marshall E, Liverman D (2014) Ch. 6: Agriculture. In Melillo JM, Richmond TC, and Yohe GW (eds) Climate change impacts in the United States: the third national climate assessment. U.S. Global Change Research Program, pp 150-174. https:/doi. org/10.7930/J02Z13FR

Hogan J (2013) Vegetable growers held their own despite 2012 drought. The County Press, 10 February 2013. $\mathrm{http}: / /$ thecountypress.mihomepaper.com/news/2013-02-10/News/Vegetable growers held their own despite_2012_drou.html (Accessed 3 Nov 2016)

Howden SM, Soussana F, Tubiello FN, Chhetri N, Dunlop M, Meinke H (2007) Adapting agriculture to climate change. Proc Natl Acad Sci U S A 104:19691-19696. https://doi.org/10.1073/pnas.0701890104

Johnson A, Morton LW (2015) Midwest climate and specialty crops: specialty crop leader views and priorities for Midwest specialty crops. Sociology technical report 1039. Department of Sociology, Iowa State University, Ames, Iowa, p 22

Johnson LF, Cahn MD, Martin F, et al (2013) New tools for ET estimation and irrigation management in specialty crops. ASABE Annual International Meeting, Paper No. 131595001. American Society of Agricultural and Biological Engineers, St. Joseph, Michigan. https://doi.org/10.13031/aim.20131595001

Kerr JT, Pindar A, Galpern P et al (2015) Climate change impacts on bumblebees converge across continents. Science 349:177-180. https://doi.org/10.1126/science.aaa7031

Knudson WA (2012) The economic impact of this spring's weather on the fruit and vegetable sectors. The Strategic Marketing Institute. Working paper 01-052012. Michigan State University. http://legislature.mi. gov/documents/2011-2012/CommitteeDocuments/House/Agriculture/Testimony/Committee1-5-30-2012. pdf. Accessed 14 Nov 2016 
Koster RD, Schubert SD, Suarez MJ (2009) Analyzing the concurrence of meteorological droughts and warm periods, with implications for the determination of evaporative regime. J Clim 12:3331-3341. https:/doi. org/10.1175/2008JCLI2718.1

Kunkel KE, Karl TR, Book H et al (2012) Monitoring and understanding trends in extreme storms: state of knowledge. Bull Am Meteorol Soc 94:499-514. https://doi.org/10.1175/BAMS-D-11-00262.1

Labe Z, Ault T, Zurita-Milla R (2016) Identifying anomalously early spring onsets in the CESM large ensemble project. Clim Dyn doi. https://doi.org/10.1007/s00382-016-3313-2

Marino GP, Kaiser DP, Gu L, Ricciuto DM (2011) Reconstruction of false spring occurrences over the southeastern United States 1901-2007: an increasing risk of spring freeze damage? Environ Res Lett 6: 024015. https://doi.org/10.1088/1748-9326/6/2/024015

Maurer A (2012) Drought stress starting to set in on specialty and produce crops. Purdue University. University News Service. 24 July 2012. https:/www.purdue.edu/newsroom/releases/2012/Q3/drought-stress-startingto-set-in-on-specialty-and-produce-crops.html. Accessed 3 Nov 3, 2016

Melillo JM, Richmond TC, Yohe GW (2014) Climate change impacts in the United States: The third national climate assessment. U.S. Global Change Research Program, pp 841. https://doi.org/10.7930/J02Z13F

Mir RR, Zaman-Allah M, Sreenivasulu N, Trethowan R, Varshney RK (2012) Integrated genomic, physiology and breeding approaches for improving drought tolerance in crops. Theor Appl Genet 125:625-645. https://doi.org/10.1007/s00122-012-1904-9

Moretti CL, Mattos LM, Calbo AG, Sargent SA (2009) Climate changes and potential impacts on postharvest quality of fruit and vegetable crops: a review. Food Res Int 43:1824-1832. https://doi.org/10.1016/j. foodres.2009.10.013

Morton LW, Hobbs J, Arbuckle J, Loy A (2015) Upper Midwest climate variations: farmer responses to excess water risks. J Environ Qual 44:810-822. https://doi.org/10.2134/jeq2014.08.0352

Nair A, Kaspar T, Nonnecke G (2015) Cover crops in vegetable production systems. Iowa State University Extension and Outreach. HORT3026, Ames, IA, pp 7

National Agricultural Statistics Service (2015) 2012 census of agriculture, specialty crops. Volume 2 subject series part 8. AC-12-S-8. United States Department of Agriculture, Washington, DC, p 29 https://www.agcensus.usda. gov/Publications/2012/Online_Resources/Specialty_Crops/SCROPS.pdf. Accessed 1 Oct 2016

National Resource Conservation Service (2006) NRCS fertility recommendations for irrigated specialty crops on coarse textured soils. Illinois agronomy technical note no. 18. National Resources Conservation Service, Champaign, IL

Olen B, Wu J, Langpap C (2015) Irrigation decisions for major west coast crops: water scarcity and climatic determinants. Am J Ag Econ 98:254-275. https://doi.org/10.1093/ajae/aav036

Potts SG, Biesmeijer JC, Kremen C, Neumann P, Schweiger O, Kunin WE (2010) Global pollinator declines: trends, impacts and drivers. Trends Ecol Evol 25:345-353. https://doi.org/10.1016/j.tree.2010.01.007

Pryor SC, D. Scavia, C. Downer, M. Gaden, L. Iverson, R. Nordstrom, J. Patz, and G. P. Robertson (2014) Ch. 18: Midwest. In Melillo JM, Richmond TC, and Yohe GW (eds) Climate change impacts in the United States: The third national climate assessment. U.S. Global Change Research Program, pp 418-440. https://doi.org/10.7930/J0J1012N

Ravanlou A, Babadoost M (2015) Development of bacterial spot, incited by Xanthomonas cucurbitae, in pumpkin fields. Hortscience 50:714-720

Rijal I (2017). Use of water mist to protect tree fruits from spring frost damage. Dissertation. Department of Geography, Michigan State University

Risk Management Agency (2015) Report to congress: specialty crop report. United States Department of Agriculture, Federal Crop Insurance Corporation. United States Department of Agriculture, Washington, DC, p 20 http:/www.rma.usda.gov/pubs/2015/specialtycrop.pdf. Accessed 19 Oct 2016

Rubatzky VE, Yamaguchi M (2012) Sweet corn. In: world vegetables: principles, production, and nutritive values, 2nd edn. Springer, New York, p 246

Sekle L (1995) Fruit cracking in sweet cherries (Prunus avium L.). Some physiological aspects-a mini review. Sci Hortic 63:135-141

Sigler D (2012) Spring freezes leave small crop, more questions. Fruit Growers News. 13 June 2012. http://fruitgrowersnews.com/article/spring-freezes-leave-small-crop-more-questions. Accessed 14 Nov 2016

Sigler D (2013) Protecting your fruit from frost and freeze. Fruit Growers News. 25 Jan 2013. http://fruitgrowersnews.com/article/protecting-your-fruit-from-frost-and-freeze/. Accessed 9 Jan 2017

Tobin PC, Nagarkatti S, Loeb G, Saunders MC (2008) Historical and projected interactions between climate change and insect voltinism in a multivoltine species. Glo Change Biol 14:951-957. https://doi.org/10.1111 j.1365-2486.2008.01561.x

Vallat A, Gu H, Dorn S (2005) How rainfall, relative humidity and temperature influence volatile emissions from apple trees in situ. Phytochemistry 66:1540-1550. https://doi.org/10.1016/j.phytochem.2005.04.038 
Veeck G, Che D, Veeck A (2006) America's changing farmscape: a study of agricultural tourism in Michigan. Prof Geogr 58:235-248. https://doi.org/10.1111/j.1467-9272.2006.00565.x

Vilsack T, Reilly JT (2015) 2012 census of agriculture: specialty crops. Volume 2. Subject series. Part 8. AC-12S8. United States Department of Agriculture. National Agricultural Statistics Service, Washington DC, p 29 https://www.agcensus.usda.gov/Publications/2012/Online_Resources/Specialty_Crops/SCROPS.pdf. Accessed 4 Nov 2016

Walthall CL, Hatfield J, Backlund P et al (2012) Climate change and agriculture in the United States: effects and adaptation. USDA Technical Bulletin 1935, Washington, DC, p 186

Xu C, Zhang Y, Zhu L, Huang Y, Lu J (2011) Influence of growing season on phenolic compounds and antioxidant properties of grape berries from vines grown in a subtropical climate. J Agric Food Chem 59: 1078-1086. https://doi.org/10.1021/jf104157z

Young E, Johnson D, Krissoff B, Lucier G. Relaxing Fruit and Vegetable Planting Restrictions (2007) Amber Waves. https:/www.ers.usda.gov/amber-waves/2007/february/relaxing-fruit-and-vegetable-plantingrestrictions/. Accessed 23 Jan 2017 